DOI: http://dx.doi.org/10.18203/2320-1770.ijrcog20191226

Original Research Article

\title{
Obstetric outcome in elderly gravida
}

\section{Supriya S. Gaikwad*, Kamlesh R. Chaudhari, Karuna Batheja}

Department of Obstetrics and Gynecology, K. J. Somaiya Medical College and Research Centre, Mumbai, Maharashtra, India

Received: 31 January 2019

Accepted: 06 March 2019

\section{*Correspondence:}

Dr. Supriya Gaikwad,

E-mail: sweetriya4336@gmail.com

Copyright: (C) the author(s), publisher and licensee Medip Academy. This is an open-access article distributed under the terms of the Creative Commons Attribution Non-Commercial License, which permits unrestricted non-commercial use, distribution, and reproduction in any medium, provided the original work is properly cited.

\section{ABSTRACT}

Background: Maternal age is an important determinant of the outcome of pregnancy. Advanced maternal age generally signify age after 35 years at the time of delivery. It is associated with decreased fertility and increased risk. Elderly gravida is associated with many complications during pregnancy, labour and also for the baby. In recent times women has changed their lifestyles such as pursuit of higher education and entry into work forces and career advancement outside the home.

Methods: This was a retrospective study done in 57 elderly pregnant women more than 33 years age, over a period of 18 months, conducted in a multi-specialty hospital.

Results: 57 elderly pregnant women were selected for the study. 47\% were in age group of 33-35 years and $42 \%$ were in age group of 36-40 years. $61.40 \%$ patients were housewives and $38.59 \%$ were employed. $50.8 \%$ of patients had history of previous abortions and $35 \%$ were conceived after treatment for sterility. $64.9 \%$ of patients conceived spontaneously and $35 \%$ by assisted reproductive technology. Majority of patients (33.3\%) required Invitrofertilization. Multiple pregnancy was high- $21.05 \%$. Hypertension was observed in $26.3 \%$ of patients, Antepartum haemorrhage in $4.34 \%$, Preterm delivery $49.1 \%$, Induction of labour in $10.52 \%$, Normal vaginal delivery only in $14 \%$. Majority of patients $(80.7 \%)$ were delivered by caesarean section.

Conclusions: Elderly pregnant patients have higher risks of specific pregnancy complications which contribute to a higher frequency of maternal morbidity and greater health care costs. The risks are due to Hypertension, diabetes, multiple pregnancy, preterm labour, antepartum haemorrhage, PROM, malpresentation, prolonged labour, increased caesarean section rate and postpartum haemorrhage.

Keywords: Assisted reproductive technology, Antepartum haemorrhage, Elderly gravida, Multiple pregnancy, Preterm delivery

\section{INTRODUCTION}

Maternal age is an important determinant of the outcome of pregnancy.

Who is the elderly gravida? That is the question that still remains not satisfactorily answered even today. The majority of writers apply the term to a woman over the age of $35 .{ }^{1}$ Other writers also suggest that from 30 years of age, a gravida becomes elderly. While advances in medical care can help women over age 35 years have safer pregnancies than in the past, infertility and pregnancy complications for this age group are higher than for younger women., ${ }^{2,3}$ The trend of delaying pregnancy by women is worldwide and observed in both low- and high-income countries, especially among more educated and financially secure women. Wide educational and career choices encourage women to pursue their professional goals. Easy access to modern contraceptive methods has enabled them to achieve better 
fertility control. ${ }^{4}$ Increasing rates of divorce is another cause for delay in conceiving. Primary and secondary infertility due to various reasons may also cause a delayed conception. ${ }^{5}$

In India, the scenario is different where poor socioeconomic status, lack of contraceptive knowledge, religious issues, desire for male child, concept of large family and women conceiving from marriage to menopause, are the common causes of pregnancy with advanced maternal age. The increased incidence of underlying medical diseases decreased cardiovascular reserve, and diminished ability to adapt to physical stress that may accompany aging could combine to increase maternal morbidity or even mortality.

Elderly women are at higher risk of several complications such as Hypertension, diabetes, anaemia, multiple pregnancy, preterm labour, antepartum haemorrhage, PROM, malpresentation, fibroid, prolonged labour, increased caesarean section rate and post-partum haemorrhage. ${ }^{6}$ As fertility declines with age, there is a greater use of assisted reproductive technologies (ARTs) and the possibility of multiple pregnancy increases. This may independently adversely affect the risks reported. ${ }^{7}$

\section{METHODS}

It was a retrospective study conducted in Department of Obstetrics and Gynaecology for 18 months. During this study period 57 patients of more than 33years of age were selected.

\section{Exclusion criteria}

- All pregnant women below 33 years age.

- Women willing for MTP with age $>33$ years.

- Patients not willing for participation in the study.

- Patients with chronic renal failure, severe cardiac disease, chronic liver disease, pulmonary tuberculosis and COPD.

- Pregnant women before 20 weeks of gestation.

All the patients above age 33 years were analysed for 18 months after 20 weeks of gestation. Maternal outcome analysed such as Hypertension, diabetes, anaemia, multiple pregnancy, preterm labour, antepartum haemorrhage, premature rupture of membranes (PROM), malpresentation, fibroid, prolonged labour, mode of delivery, operative vaginal delivery, caesarean section, postpartum haemorrhage. Information related to patient's demographical information, previous obstetric history, and mode of conception was analysed.

\section{RESULTS}

According to our data, $47 \%$ of the patients were in $33-35$ years age group and $42 \%$ were in age group $36-40$ years. Maximum age of the patient was 46yrs. $>45$-year age group had only 1 patient $(1.75 \%$ ) (Table 1$)$.
Table 1: Age wise distribution of cases.

\begin{tabular}{|l|l|l|l|}
$\begin{array}{l}\text { Age of } \\
\text { the } \\
\text { mother } \\
\text { (years) }\end{array}$ & $\begin{array}{l}\text { No. of } \\
\text { patients } \\
(\mathbf{n}=57)\end{array}$ & $\begin{array}{l}\text { Primigravidae } \\
(\mathbf{n = 1 9 )}\end{array}$ & $\begin{array}{l}\text { Multigravidas } \\
(\mathbf{n}=38)\end{array}$ \\
\hline $33-35$ & $27(47.36)$ & $10(37)$ & $17(62.9)$ \\
\hline $36-40$ & $24(42.10)$ & $6(25)$ & $18(75)$ \\
\hline $41-45$ & $5(8.77)$ & $3(60)$ & $2(40)$ \\
\hline$>45$ & $1(1.75)$ & 0 & 1 \\
\hline Total & $57(100)$ & $19(33.3)$ & $38(66.6)$ \\
\hline
\end{tabular}

Majority of patients were housewives $61.40 \%$ and $38.59 \%$ were employed (Table 2).

Table 2: Occupation of mother.

\begin{tabular}{|l|l|}
\hline Occupation & No. of patients \\
\hline Housewife & $35(61.40)$ \\
\hline Employed & $22(38.59)$ \\
\hline
\end{tabular}

In our data $50.8 \%$ of patients had history of previous abortions and $35 \%$ were conceived after treatment for sterility. $8.67 \%$ patients gave preference for male child as cause for delay in conception. Late marriage was in $5.26 \%$ of cases (Table 3 ).

Table 3: Causes of delay in pregnancy.

\begin{tabular}{|l|l|}
\hline Causes & No. of women \\
\hline Abortions & $29(50.87)$ \\
\hline Ectopic pregnancy & $5(8.67)$ \\
\hline Treatment for sterility & $20(35.08)$ \\
\hline Late marriage & $3(5.26)$ \\
\hline Preference for male child & $5(8.67)$ \\
\hline
\end{tabular}

According to our data, $64.9 \%$ of patients conceived spontaneously and remaining required assisted reproductive technology $(35 \%)$, majority of patients $(33.3 \%)$ required Invitro fertilization among them $5.2 \%$ of patients were conceived with IVF using donor oocyte. IUI was done in 1 patient $(1.75 \%$ ) (Table 4$)$.

Table 4: Mode of conception.

\begin{tabular}{|l|l|}
\hline Mode of conception & Number of patients \\
\hline Natural & $37(64.91 \%)$ \\
\hline IVF & $19(33.33 \%)$ \\
\hline With donor oocyte & $3(5.26 \%)$ \\
\hline IUI & $1(1.75 \%)$ \\
\hline
\end{tabular}

According to our data, Because of use of assisted reproductive technology, multiple pregnancy rates were high. $22.8 \%$ of patients had twin pregnancy (Table 5). Hypertension was observed in $26.3 \%$ of patients all of them were cases of pregnancy induced hypertension. $3.5 \%$ of patients were of gestational diabetes. $10.5 \%$ of patients were anaemic. Preterm labour was observed in $14 \%$ of cases. PROM was observed in 9 patients $(15.7 \%)$. 
Malpresentation like Breech and transverse lie were observed in $10.5 \%$ of cases.

Table 5: Pregnancy complications.

\begin{tabular}{|l|l|}
\hline Complications & No of patients (\%) \\
\hline Hypertension & $15(26.3)$ \\
\hline Diabetes & $2(3.5)$ \\
\hline Anemia & $6(10.5)$ \\
\hline Multiple pregnancy & $13(22.80)$ \\
\hline Preterm labour & $8(14)$ \\
\hline Antepartum hemorrhage & $2(3.5)$ \\
\hline PROM & $9(15.7)$ \\
\hline Malpresentation & $6(10.5)$ \\
\hline Fibroid & $2(3.5)$ \\
\hline Prolonged labour & $5(8.7)$ \\
\hline Post-partum hemorrhage & $2(3.5)$ \\
\hline
\end{tabular}

Labour was prolonged in $8.7 \%$ of cases. Post-partum haemorrhage was seen in $3.5 \%$ of cases. Majority of the patients $(80.7 \%)$ were delivered by caesarean section. Out of $14 \%$ of patients who had delivered vaginally almost all had required induction of labour (10.5\%). In present study preterm delivery rate was as high as $49 \%$. Operative vaginal delivery was required in only 1 patient (Table 6).

Table 6: Labour outcome among the women.

\begin{tabular}{|l|l|}
\hline Outcome & No. patients \\
\hline Normal vaginal deliveries & $8(14 \%)$ \\
\hline Operative vaginal deliveries & $1(1.75 \%)$ \\
\hline Induction of labour & $6(10.52 \%)$ \\
\hline Preterm delivery & $28(49.1 \%)$ \\
\hline Caesarian section & $46(80.7 \%)$ \\
\hline
\end{tabular}

\section{DISCUSSION}

This study group comprised of elderly pregnant women 33 years or older, 57 women were assessed to determine the effect of age on maternal outcomes after 20 weeks of gestation. In present study $47.3 \%$ women were in age group 33-35 years, $42.1 \%$ in $36-40$ years group, $8.7 \%$ in 41-45-year group and $1.7 \%$ in $>45$ years age group. In the study of B. Luke and M.B. Brown, 59\% women were in age group 30-34 years, $31 \%$ were in $35-39$ years, $7.8 \%$ in $40-44 y$ rs and $0.4 \%$ were $>45$ years. $^{8}$ In present study $61.4 \%$ of women were housewives and $38.55 \%$ were employed. W. Marai and Z. Lakew, in their study $63 \%$ were housewives and $26 \%$ were employed. $35 \%$ of patients in present study had history of infertility and required assisted reproductive technology for conception. ${ }^{9}$ Marzieh Nojomi and his associates in 2010 had $25.5 \%$ of patients with history of infertility. ${ }^{10}$

\section{Complications in pregnancy}

The increased incidence of diabetes and hypertension in present study confirms prior reports (Paulson et al; Salihu et al) and most likely reflects the age-related changes. ${ }^{11,12}$ Associated risk factors such as hypertension and diabetes account for increased incidences of placental abruption, intra-uterine growth retardation and (pre-)eclamptic disease, all of them being associated with a higher risk for (emergency) Caesarean section. In present study group. Authors found the incidence of Hypertension of $26.3 \%$. W. Marai, Z. Lakew in observed rate of hypertension of $19 \% .^{9}$ KE Fitzpatrick et al observed rate of hypertension of $15 \% .{ }^{13}$ In present study $3.5 \%$ of patients were diabetic, Marzieh Nojomi and his associates in found incidence of diabetes of $3.7 \%$ in his study. ${ }^{10}$ Incidence of anemia in present study was $10.5 \%$, Moses et al found incidence of anemia of $19 \% .^{14}$ The rate of multifetal gestation was higher in the study group, largely because of artificial reproductive technologies, which explains the higher rates of preterm labour and caesarian section delivery. In present study $5.2 \%$ of patients conceived with IVF techniques using donor oocytes, In vitro fertilization was required in $33.3 \%$ of cases and intrauterine insemination was required in $1.7 \%$ of cases. In present study $22.80 \%$ of women were with multiple pregnancy. In the study of Richard P. Porreco, Leslie Harden in April, incidence of women conceived with assisted reproductive technology was $78 \%$ and the Rate of multiple pregnancies was $48 \% .^{15}$

The rate of preterm delivery in present study was 49\%.Yariv y, Melamed N, Tenenbaum-Gavish K et al found rate of 54\% in 30-39 years age group,42\% in 40-45 years and $15 \%>45$ years age group. ${ }^{16}$ Malpresentation was observed in $10.5 \%$ in present study. Ezechi OC and associates in 2007 found the incidence of $9.1 \%$ in their study. ${ }^{17}$ Awad Shehadeh, in his study rate of fibroid was $2.9 \%$ and authors found the rate of fibroid of $3.5 \%$ in our patients. ${ }^{18}$

\section{Management of labour}

In present study the pregnancy was terminated by induction in $10.5 \%$ of cases. W.Marai and Z. Lakew in found induction rate of $13.2 \%$ in their study. ${ }^{9}$ In present study total caesarian section rate was $80 \%$ which was higher than Rajput $\mathrm{N}$ et al who found the rate of caesarean section of $35.41 \%$, Yariv Y, Melamed N, Tenenbaum-Gavish $\mathrm{K}$ et al, in found caesarian section rate of $78.5 \% .^{16,19}$ Postpartum haemorrhage was found in $3.5 \%$ of our patients. In July 2010 Yun Wang and Tom Tanbo found postpartum haemorrhage in $18.5 \%$ of elderly women. ${ }^{20}$

\section{CONCLUSION}

The study of complications and obstetric outcome in women with elderly gravida is important. Elderly pregnant patients have higher risks of complications such as Hypertension, diabetes, multiple pregnancy, preterm labour, antepartum haemorrhage, PROM, malpresentation, prolonged labour, increased caesarean section rate and postpartum haemorrhage. This study 
defines the importance of both counselling and following patients for specific adverse outcomes associated with advancing maternal age. Many of these risks can be successfully managed through preconception and prenatal care. Focused care for women over age 33 plays a vital role in minimizing health risks, sensitively meeting their unique psychosocial needs, and maximizing health opportunities to achieve the best possible outcome.

\section{ACKNOWLEDGMENTS}

Authors would like to thank Dr. Kamlesh Chaudhary for the support during study.

\section{Funding: No funding sources}

Conflict of interest: None declared

Ethical approval: The study was approved by the Institutional Ethics Committee

\section{REFERENCES}

1. Nathanson JN. A parallel study of labor in young and old primiparas: Based upon a critical analysis of 372 cases below twenty and above thirty-five years of age. Am J Obstet Gynecol. 1935;30(2):159-73.

2. Rucker MP. Mono-amniotic twins: With both umbilical cords about the first twin's neck. Am J Sur. 1935;28(1):175-6.

3. Young, J. Relaxation of the pelvic joints in pregnancy: pelvic arthropathy of pregnancy. J Obstet Gynaecol Br Emp. 1940;47(5):493-524.

4. Laxmy R, Beena G. Pregnancy outcome in women of advanced maternal age. Int J Bioassays. 2013; 2(9):1193-8.

5. Paulson RJ, Boostanfar R, Saadat P, Mor E, Tourgeman DE, Slater CC, Francis MM, Jain JK. Pregnancy in the sixth decade of life: obstetric outcomes in women of advanced reproductive age. Jama. 2002;288(18):2320-3.

6. Tebeu PM, Kouam L, Nghonguia MF, Obama MT, Major AL, Ludicke F(2007). [historical cohort study of delivery in women of forty years of age and older]. Rev Med Liege;62(7-8):509-14.

7. Krieg SA, Henne MB, Westphal LM. Obstetric outcomes in donor oocyte pregnancies compared with advanced maternal age in in vitro fertilization pregnancies. Fertil Steril. 2008;90(1):65-70.

8. Luke B, Brown MB. Elevated risks of pregnancy complications and adverse outcomes with increasing maternal age. Human Reproduct. 2007;22(5):126472.

9. Marai W, Lakev Z. Pregnancy outcome in the elderly gravida in Addis Ababa. East African Med J. 2002;79(1):34-7.

10. Nojomi M, Haghighi L, Bijari B, Rezvani L, Tabatabaee SK. Delayed childbearing: pregnancy and maternal outcomes. Iranian J Reproduct Med. 2010;8(2).

11. Paulson RJ, Boostanfar R, Saadat $\mathrm{P}$, Mor E, Tourgeman DE, Slater CC, Francis MM, Jain JK. Pregnancy in the sixth decade of life: obstetric outcomes in women of advanced reproductive age. Jama. 2002;288(18):2320-3.

12. Salihu HM, Shumpert MN, Slay M, Kirby RS, Alexander GR. Childbearing beyond maternal age 50 and fetal outcomes in the United States. Obstet Gynecol. 2003;102(5):1006-14.

13. Fitzpatrick KE, Tuffnell D, Kurinczuk JJ, Knight M. Pregnancy at very advanced maternal age: a UK population-based cohort study. BJOG: An International J Obstet Gynaecol. 2017;124(7):1097106.

14. Moses V, Dalal N. Pregnancy outcome in elderly primi gravidas. Int $\mathbf{J}$ Reprod Contracept Obstet Gynecol. 2016;5(11):3731-55.

15. Porreco RP, Harden L, Gambotto M, Shapiro H. Expectation of pregnancy outcome among mature women. Am J Obstet Gynecol. 2005;192(1):38-41.

16. Yogev Y, Melamed N, Bardin R, Tenenbaum-Gavish K, Ben-Shitrit G, Ben-Haroush A. Pregnancy outcome at extremely advanced maternal age. Am J Obstet Gynecol. 2010;203(6):558-e1.

17. Ezechi OC, Kalu BK, Loto OM, Ezeobi PM, Nwokoro CA. Obstetric performance in elderly Nigerian women: A comparative study. Nepal J Obstet Gynaecol. 2007;2(1):9-12.

18. Shehadeh A, Elderly primigravida and pregnancy outcome. JRMS. 2002;9(2):8-11.

19. Rajput $\mathrm{N}$ et al. Int J Reprod Contracept Obstet Gynecol. 2018;7(10):3941-5

20. Wang Y, Tanbo T, Åbyholm T, Henriksen T. The impact of advanced maternal age and parity on obstetric and perinatal outcomes in singleton gestations. Arch Gynecol Obstet. 2011;284(1):31-7.

Cite this article as: Gaikwad SS, Chaudhari KR, Batheja K. Obstetric outcome in elderly gravida. Int J Reprod Contracept Obstet Gynecol 2019;8:1606-9. 